$(16,7 \%)$, không có trường hợp nặng xin về và không có trường hợp tử vong tại bệnh viện. Qua đây cho thây, nạn nhân chủ yếu bệnh nhẹ, có thể chăm sóc theo dõi tại nhà nên tỷ lệ cấp đơn cho về và điều trị ngoại trú cao, qua đó cũng sàng lọc được bệnh nhẩn, hạn chế tối đa bệnh nhân phải chuyển tuyến. Tỷ lệ chuyển tuyến ngày càng giảm vì hiện nay, bệnh viện chúng tôi đã đâu tư trang thiết bị hiện đại như máy chụp CT Scanner, siêu âm màu 4 chiêu góp phân trong chẩn đoán, tiên lượng, điêu trị, hạn chế bệnh nhân phải chuyển tuyến.

\section{KẾT LUÂ̂N}

Tỉ lệ sơ cứu trước khi vào viện thấp. Đa số là người xung quanh tham gia sơ cứu. Phương tiện vận chuyển người bị tai nạn chủ yếu là xe máy.

\section{TÀI LIÊU THAM KHẢO}

1. Đoàn Văn Ánh, Vũ Minh Hải (2016), Nhận xét thức trang cấp cứu ban đầu bênh nhân chấn thương do tai nan giao thông điều trị tại khoa Chấn thương Chỉnh hình - Bỏng Bệnh viện đa khoa tỉnh
Thái Bình năm 2016. Đề tài nghiên cứu khoa học cấp cơ sở, Trường Đai học Y dược Thái Bình.

2. Vũ Mạnh Độ (2013), Thực trạng và hậu quả thương tích giao thông đường bộ ở người bệnh điều tri tai Bênh viên đa khoa tỉnh Nam Định 3 tháng đầu năm 2013, Luận văn thạc sỹ Y tế công công, Đai học Y dước Thái Bình.

3. Đồng Ngọc Đức (2009), Thực trạng sơ cấp cứu tai nạn giao thông ngoài bênh viên khu vực Hà Nôi năm 2007 - 2008, Tạp chí Y học thực hành, (650), số 3/2009.

4. Huỳnh Thị Kim Khơi (2016), Thực trang tai nạn giao thông đường bộ và chi phí điêu trị của bệnh nhân vào khoa cấp cứu Bênh viện đa khoa Hậu Giang tỉnh Hậu Giang năm 2015, Luận văn Thạc sỹ Y tế công cộng, Học viện Quân Y.

5. Lê Thi Hông Lînh (2014), Thực trạng và công tác cấp cứu tai nạn giao thông đường bộ tại Bệnh viện đa khoa Viêt Tiệp Hải Phòng năm 2013, Luận vằn Thạc sỹ Y tế công cộng, Đại học Y dược Hải Phòng.

6. Yang C. S., S. C. Ċhen, et al. (2017), Epidemiology and patterns of facial fractures due to road traffic accidents in Taiwan. A 15 years retrospective study, Traffic Inj Prev.

7. Andrade S. S. and M. H. Jorge (2017), Hospitalization due to road traffic injuries in Brazil, 2013: hospital stay and costs, Epidemiol Serv Saude, 26(1).

\title{
TẦN SUẤT VÀ CÁC YẾU TỐ ĐộC LỰC CỦA HELICOBACTER PYLORI Ở BÊ̂NH NHÂN VIỂM DẠ DÀY MẠN
}

\section{Phạm Hồng Khánh², Trần Thị Huyền Trang1, Nguyễn Quang Duật ${ }^{2}$, Vũ Văn Khiên ${ }^{1}$}

\section{TÓM TẮT}

Đắt vấn đề: Nhiễm $H$. pylori đã được khẳng đinh là nguyển nhân chủ yếu gây viêm dạ dày man và loét dạ dày - tá tràng và đặc biệt là ung thư da dày. Mục tiêu: Nghiên cứu về tần tần suất nhiễm $\mathrm{H}$. pylori và tỷ lệ cagA, vacA ở bệnh nhân viêm dạ dày mạn. Đối tượng \& phương pháp: Chẩn đoán VDDM dựa trên nội soi và mô bệnh học. Chẩn đoán nhiễm $\mathrm{H}$. pylori dựa trên: Nuôi cấy, mô bênh học và CLO test. Xét nghiệm cagA và vacA bằng kỹ thuật $P C R$ tại khoa Sinh học phân tửBênh viện TWQĐ 108. Kết quả: Có 121 bệnh nhân VDDM được đưa vào nghiên cứu, với tuổi trung bình là: $45,2 \pm 11,8$ (18-78 tuổi), tỷ lệ: nữ/nam = 1,16. Tỷ lề $\mathrm{H}$. pylori ở bệnh nhân viêm da dày mạn là: 77/121 $(63,7 \%)$. Tỷ lê cagA dương tính đat: $70 / 71$ (98,6\%) trong đó tỳ lệ cagA Đông A chiếm: 67/71 (94,4\%). Tý lệ vacAs1 chiếm: 71/71 (100\%). Phân bố các týp vacA:

${ }^{1}$ Bệnh viện TWQĐ 108

²Bệnh viện 103- Học viện Quân y

Chịu trách nhiệm chính: Vũ Văn Khiên

Email: vuvankhien108@yahoo.com.vn

Ngày nhận bài: 2.6.2021

Ngày phản biện khoa học: 26.7.2021

Ngày duyệt bài: 3.8.2021
vacAs1 $m 1$, vacAs1 $m 2$ và vacA i1 chiếm tỷ lệ tương ứng là: $46,5 \% ; 50,7 \%$ và $94,4 \%$. Kết luận: Tỷ lệ các gen vacA, cagA tăng cao hơn ở bệnh nhân viêm dạ dày mạn có nhiếm Helicobacter pylori.

Tư viết tắt: viêm dạ dày mạn, Helicobacter pylori.

\section{SUMMARY}

\section{PREVALENCE AND VIRULENCE FACTORS OF HELICOBACTER PYLORI IN PATIENTS WITH CHRONIC GASTRITIS}

Introduction: $\mathrm{H}$. pylori infection has been confirmed to be the main cause of chronic gastritis, peptic ulcer and especially gastric cancer. Objectives: Research on the prevalence of $\mathrm{H}$. pylori and cagA, vacA in patients with chronic gastritis. Patients \& methods: Diagnosis of chronic gastritis is based on endoscopy and histopathology. Diagnosis of $\mathrm{H}$. pylori infection is based on culture, histopathology and CLO test. cagA and vacA were determined by PCR at the department of Molecular Biology - 108 Central. Results: 121 patients with chronic gastritis were included in the study, with the mean age: $45.2 \pm 11.8$ (18-78 years old), female/male $=1.16$. The rate of $\mathrm{H}$. pylori in patients with chronic gastritis was $77 / 121$ $(63.7 \%)$. The rate of cagA positive was 70/71 $(98.6 \%)$, in which the rate of East- Asia-type cagA 
accounted for: $67 / 71(94.4 \%)$. The rate of vacA s1 positive was $71 / 71(100 \%)$. The vacAs1 $\mathrm{m} 1$, vacAs1 $\mathrm{m} 2$ and vacA i1 genes were detected in rates of $46.5 \% ; 50.7 \%$ and $94.4 \%$, respectively. Conclusion: The vacA, cagA genes was higher in patients with chronic gastritis with Helicobacter pylori infection.

Key words: chronic gastitis, Helicobacter pylori.

\section{I. ĐĂT VẤN ĐỀ}

Nhiễm Helicobacter pylori (H. pylori) đến nay đã được khẳng định là nguyên nhân chủ yếu gây viêm dạ dày mạn và loét dạ dày - tá tràng và đặc biêt là ung thư da dày. Cho đến nay, Tổ chức $Y$ tế thế giới đã xếp $\mathrm{H}$. pylori nằm trong tác nhân số 1 gây ung thư dạ dày. Có khoảng $50 \%$ dân số trên thế giới nhiễm H.pylori. Tân suất nhiễm $\mathrm{H}$. pylori thay đổi theo từng châu lục và các quốc gia khác nhau [1],[2]. Việt Nam là một quốc gia có tỷ lệ nhiễm $\mathrm{H}$. pylori cao trong cộng đồng (khoảng 70\%). Khả năng gây bệnh của H. pylori phụ thuộc nhiêu vào các yếu tố độc lực của $H$. pylori. Các yếu tố độc lực của $H$. pylori như: cag-PAI, cagA, vacA, babA, opiA, iceA, dupA và homB [1],[2]. Tuy nhiên, chỉ có 2 gen cagA và vacA được nghiên cứu nhiều nhất trong các bệnh lý dạ dày khác nhau, trong đó có viêm dạ dày man (VDDM). Đề tài nghiên cứu này nhằm mục tiêu: Nghiên cứu về tần tần suất nhiễm $\mathrm{H}$. pylori và tỷ lệ cagA, vacA ở bệnh nhân VDDM.

\section{II. ĐỐI TƯỢNG VÀ PHƯƠNG PHÁP NGHIÊN CỨU}

1. Đối tượng: 121 bệnh nhân VDDM được thu thâp từ Bểnh viện TWQĐ 108 và Bệnh viện 103 (Học viện Quân y). Thời gian thu thâp số liệu: 12/2019 đến 12/2020.

Tiêu chuẩn lựa chọn: Chẩn đoán VDDM dựa trên kết quả nội soi và mô bênh học. Bệnh nhân không sử dụng các loại kháng sinh, chất chứa Bisthmus, thuốc ức chế bài tiết acid dịch vị dạ dày trong vòng 1 tháng trước nghiên cứu.

Tiêu chuẩn loại trừ: Bệnh nhân có tiền sử phẫu thuật dạ dày..

\section{Phương pháp}

*Thiết kế nghiên cứu: Mô tả, cắt ngang, tiến cứu.

*Lập hồ sơ: Trước khi nội soi, tất cả bệnh nhân được phỏng vấn theo mẫu bênh án nghiên cứu, điều tra về tiền sử bệnh, khám lâm sàng, xét nghiệm cận lâm sàng.

*Nôi soi da dày: Thực hiên trên máy nôi soi da dày ống mềm (CV 180-Olympus-Nhật Bản). Sinh thiết qua nội soi: Làm CLO test (01 mảnh tại hang vị), nuôi cấy (02 mảnh: 1 hang vị và 1 thân vị), mô bênh học (02 mảnh: hang vị và thân vị). Các mẫu mô dùng để nuôi cấy $\mathrm{H}$. pylori sẽ được vùi trong môi trường nuôi cấy (Transport Medium), sau đó được bảo quản ở nhiêt độ $-80^{\circ} \mathrm{C}$. Chẩn đoán VDDM dựa theo hệ thống phân loại Sydney cập nhật. Tỷ lệ nhiễm H. pylori sẽ thu thập từ kết quả xét nghiệm: CLO test, mô bệnh học và nuôi cấy.

*Tiêu chuẩn chẩn đoán nhiễm $\mathbf{H}$. pylori khi: Kết quả nuôi cây $H$. pylori dương tính. Nếu nuôi cấy âm tính, xác định có nhiễm $\mathrm{H}$. pylori khi: $\mathrm{MBH}(+)$ và CLO test $(+)$

Khảo sát các yếu tố độc lực cagA và vacA bằng kỹ thuật PCR tại khoa Sinh học phân tửBệnh viện TWQĐ 108

\section{KẾT QUẢ NGHIÊN CỨU}

Trong thời gian nghiên cứu, chúng tôi đã thu thập được 121 bệnh nhân VDDM được chẩn đoán xác định trên nội soi và mô bệnh học. Sau đây là kết quả cụ thể:

Bảng 1. Phân bố tuổi và giới ở bệnh nhân VDDM

\begin{tabular}{|c|c|c|c|c|c|c|}
\hline \multirow{2}{*}{ Giới } & \multicolumn{5}{|c|}{ Phân bố tuối và giới } & \multirow{2}{*}{ Tổng } \\
\hline & $\leq 29$ & $30-39$ & $40-49$ & $50-59$ & $\geq 60$ & \\
\hline Nam & 8 & 11 & 20 & 8 & 9 & 56 \\
\hline Nữ & 11 & 13 & 21 & 14 & 6 & 65 \\
\hline Tống & $19(15,7 \%)$ & $24(19,8 \%)$ & $41(33,9 \%)$ & $22(18,2 \%)$ & $15(12,4 \%)$ & 121 \\
\hline & & Tuối t t & $\begin{array}{l}\text { g bình: } 45, \\
\text { Tỷ lệ nữ } / \mathbf{r}\end{array}$ & $\begin{array}{l}11,8(18-78 \\
1,16\end{array}$ & & \\
\hline
\end{tabular}

Nhận xét: Tuối TB: 45,2 \pm 11,8 (18-78 tuối). Tỷ lệ: Nữ/nam: 1,16

Bảng 2. Triệu chứng lâm sàng VDDM

\begin{tabular}{|c|c|c|c|c|c|c|}
\hline \multirow{2}{*}{$\begin{array}{c}\text { Triệu } \\
\text { chứng }\end{array}$} & \multicolumn{7}{|c|}{ Nhóm tuối bệnh nhân VDDM (n = 121) } \\
\cline { 2 - 7 } & Đau TV & ợ hơi & Ơ chua & Nóng rát & Buồn nôn & RLTH \\
\hline $\mathrm{n}$ & $54 / 121$ & $57 / 121$ & $49 / 121$ & $31 / 121$ & $25 / 121$ & $33 / 121$ \\
\hline$\%$ & $44,6 \%$ & $47,1 \%$ & $40,5 \%$ & $25,6 \%$ & $20,7 \%$ & $27,3 \%$ \\
\hline
\end{tabular}

Nhận xét: Các triệu chứng đau thượng vị, ợ hơi, ợ chua gặp nhiêu hơn.

\begin{tabular}{l|c|c|} 
Bảng 3. Tỷ lệ phát hiện H. pylori theo & Kỹ Thuật & Tỷ lệ H. pylori (+) \\
\cline { 3 - 3 } các phương pháp chấn đoán & Nuôi cấy & $71 / 121(58,7 \%)$ \\
\hline
\end{tabular}




\begin{tabular}{|c|c|}
\hline Mô bệnh học & $96 / 121(79,3 \%)$ \\
\hline CLO test & $91 / 121(75,2 \%)$ \\
\hline Tỷ lệ chung & $\mathbf{7 7 / 1 2 1}(\mathbf{6 3 , 6 \% )}$ \\
\hline Nhận xét: Tỷ lệ H. pylori ở bệnh nhân VDDM \\
là: 77/121 $(63,7 \%)$.
\end{tabular}

Bảng 4. Tý lệ và phân bố các týp cagA của H. pylori

\begin{tabular}{|c|c|}
\hline Phân týp cagA & n (\%) \\
\hline cagA týp Đông A & $67 / 71(94,4 \%)$ \\
\hline cagA týp phương Tây & $3 / 71(4,2 \%)$ \\
\hline cagA âm tính & $1 / 71(1,4 \%)$ \\
\hline Tỳ lệ chung & $\mathbf{7 1 / 7 1 ( 1 0 0 \% )}$ \\
\hline
\end{tabular}

Nhận xét: cagA Đông Á chiếm tỷ lệ cao nhất: $94,4 \%$.

Bảng 5. Tỷ lệ và phân bố các týp vagA của H. pylori

\begin{tabular}{|c|c|}
\hline Phâa $\boldsymbol{H}$. pyloríp cagA & $\mathbf{n ~ ( \% )}$ \\
\hline vacA s1 & $71 / 71(100 \%)$ \\
\hline vacA s2 & 0 \\
\hline vacAs1 m1 & $33 / 71(46,5 \%$ \\
\hline vacAs1 m2 & $36 / 71(50,7 \%)$ \\
\hline Không xác định & $2 / 71(2,8 \%)$ \\
\hline vacA i1 & $67 / 71(94,4 \%)$ \\
\hline vacA i2 & $4 / 71(5,6 \%)$ \\
\hline
\end{tabular}

Nhận xét: vacAs1 chiếm tỷ lệ: $100 \%$; vacAs1 $\mathrm{m} 1$, vacAs1 $\mathrm{m} 2$ và vacA i1 chiếm tỷ lệ tương ứng là: $46,5 \% ; 50,7 \%$ và $94,4 \%$

\section{BÀN LUÂNN}

1. Đặc điểm về tuổi và giới. Đã có nhiều nghiên cứu về viêm dạ dày mạn (VDDM) ở người kinh. Tuổi và giới của bệnh nhân VDDM cũng được đề cập trong các nghiên cứu khác nhau. Trong nghiên cứu của chúng tôi (bảng 1) cho biết: tuối trung bình ở bệnh nhân VDDM là: 45,2 $\pm 11,8$ (tuổi) và số bệnh nhân có tuổi từ 40-49 tuổi chiếm tỷ lệ cao nhất: 33,9\%. Kết quả cũng cho biết số bệnh nhân nữ nhiều hơn nam với tỷ lệ nữ/nam là: 1,16 .

Kết quả này cũng phù hợp với các kết quả nghiên cứu trong nước [3-6] . Tuổi trung bình ở bệnh nhân VDDM trong nghiên cứu của Nguyễn Quang Chung $(41,8 \pm 11,1)$, Nguyễn Văn Thịnh $(39,5 \pm 12,6)$, Quách Trọng Đức $(46,1 \pm 10,5)$, Hồ Đăng Quý Dũng $(43,4 \pm 13,0)$. Tỷ lệ giới (nữ/nam) có thay đổi trong các nghiên cứu khác nhau: Nguyễn Quang Chung $(1,4)$, Nguyễn Văn Thịnh $(1,3)$, Hồ Đăng Quý Dũng $(1,16)$

2. Tỷ lệ nhiễm $H$. pylori ở bệnh nhân VDDM. Hầu hết các nghiên cứu trong và ngoài nước chẩn đoán nhiễm $\mathrm{H}$. pylori đều phải được tiến hành đồng thời trên nhiều phương pháp khác nhau để tăng độ tin cậy cho kết quả nghiên cứu. Chúng tôi xác định tình trạng nhiễm $\mathrm{H}$. pylori bằng 3 xét nghiệm khác nhau. Xác định nhiễm H. pylori đầu tiên là dựa vào kết quả nuôi cấy $\mathrm{H}$. pylori dương tính. Trong trường hợp nuôi cây cho kết quả âm tính, xác định là bệnh nhân có nhiễm $\mathrm{H}$. pylori khi cả 2 xét nghiệm còn lại (mô bệnh học và CLO test) đều cho kết quả dương tính. Kết quả nghiên cứu (bảng 3) cho biết tỷ lệ nhiễm $\mathrm{H}$. pylori ở bệnh nhân VDDM là: $67 / 171(63,7 \%)$. Nếu tách riêng ra từng phương pháp khác nhau thì khả năng phát hiện $\mathrm{H}$. pylori trong xét nghiệm nuôi cấy, mô bệnh học và CLO test chiếm tỷ lệ tương ứng là: $36,5 \%, 37,4 \%$, $39,5 \%$ và $38,4 \%$.

Nghiên cứu của Nguyễn Văn Thịnh (2010) trên 279 bệnh nhân VDDM [Error! Reference source not found.4] đã sữ dụng bốn phương pháp khác nhau: Urease test, PCR, mô bệnh học và nuôi cấy cho biết tỷ lệ nhiễm $\mathrm{H}$. pylori tươning ứng là: $58,1 \%, 58,1 \%, 56,3 \%$ và $57,0 \%$. Nghiên cứu của Hồ Đăng Quý Dũng [6] với Trường Đại học Oita (Nhật Bản) ở bệnh nhân VDDM cho biết tỷ lệ nhiễm $\mathrm{H}$. pylori là: 145/242 (59,9\%). Nghiên cứu cũng cho biết: Tỷ lệ $\mathrm{H}$. pylori dương tính xét nghiệm huyết thanh, xét nghiệm nước tiêu (RAPIRUN), mô bệnh học, hóa mô miễn dịch và nuôi cấy chiếm tỷ lệ tương ứng là: $87,4 \%$; $85,8 \% ; 82,1 \% ; 82,8 \%$ và $71 \%$. Như vậy, với kết quả này cho thấy tỷ lệ $\mathrm{H}$. pylori dương tính cao hơn so với nghiên cứu của Nguyễn Văn Thịnh. Chúng tôi cho rằng kinh nghiệm và điều kiện trang thiết bị y tế đóng vai trò quaan trọng có liển quan đến kết quả chẩn đoán nhiếm H. pylori

Tỷ lệ nhiễm $H$. pylori ở bệnh nhân VDDM cũng thay đổi theo vùng miền và chủng tộc người. Nghiên cứu của Trần Thanh Bình và cS [7] ở bệnh nhân VDDM người dân tộc cho biết: Tỳ lệ nhiễm H. pylori tại Lào Cai là 201/200 bệnh nhân $(51,0 \%)$, cao hơn có ý nghĩa ( $p$ < $0,01)$ so với tỷ lệ nhiếm $\mathrm{H}$. pylori tại Đắc Lắc 86/294 bệnh nhân (29,3\%). Nghiên cứu của Lê Quang Tâm [8] trên 240 bệnh nhân viêm loét da dày tá tràng (năm 2011) ở người $\hat{E}$ Đê (tỉnh Đắc Lắc) cho biết tỷ lệ nhiễm $\mathrm{H}$. pylori bằng mô bênh học, test nhanh urease, mô bệnh học và/hoặc test nhanh urease chiếm tỷ lệ tương ứng: $60,4 \% ; 59,6 \% ; 64,2 \%$.

3. Phân bố các týp cagA của H. pylori ở bệnh nhân VDDM. Yếu tố độc lực (virulence factors) của $H$. pylori đóng vai trò quan trọng liên quan đến khả năng gây bệnh và sự hình thành ung thư dạ dày. Có hai yếu tố độc lực được đề cập nhiều nhất là: Kháng nguyên gây độc tế bào $A$ (Cytotoxin associated antigen $A$ : CagA) và độc tố gây không bào $A$ (Vacuolating cytotoxin A: VacA) [1],[2]. 
CagA là một trong các yếu tố độc lực của vi khuẩn $\mathrm{H}$. pylori được nghiên cứu nhiêuu nhất và được chia thành hai týp: cagA týp phương Tây và cagA týp Đông Á [1]. Người nhiếm $H$. pylori có mang gene cagA týp Đông Á có nguy cơ bị VDDM, loét dạ dày tá tràng và ung thư da dày cao hơn so với người mang gene cagA týp phương Tây.

Chúng tôi đã thu thập 71 mẫu $\mathrm{H}$. pylori có kết quả dương tính từ môi trường nuôi cấy, để tiến hành phân tích về tỷ lệ cagA và phân týp của cagA. Kết quả trình bày trong bảng 4 cho biết: cagA Đông Á chiếm tỷ lệ cao nhất $(94,4 \%)$. Kết quả nghiên cứu này cũng phù hợp với nghiên cứu của Hồ Đăng Quý Dũng [6], trong đó týp cagA Đông Á chiếm 91,3\%. Các nghiên cứu trên thế giới cho rằng tần suất mắc ung thư dạ dày có liên quan chặt chẽ đến gen cagA và cagA týp Đông Á. Tại vùng Đông Á, tỷ lệ mắc ung thư dạ dày gặp nhiều ở Nhật Bản, Hàn Quốc, Trung Quốc và tỷ lệ cagA, cagA týp Đông Á tại các nước này chiếm tỷ lệ > 95\% [1],[ 2]. Trong một nghiên cứu gần đây (2019), Yamaoka Y và cs khi nghiên cứu trên đối tượng có bệnh lý dạ dày tại Mông cổ thấy rằng tân suất mắc UTDD rất cao và phần lớn có liên quan đến gen cagA týp phương Tây

4. Phân bố các týp vacA của $H$. pylori ở bệnh nhân VDDM. Một yếu tố độc lực nữa của H. pylori là độc tố gây không bào vacA, nó gây nên các không bào trong bào tương. Không giống như gene cagA, gene vacA hiện diện ở hầu hết tất cả các chủng $\mathrm{H}$. pylori. Tuy nhiên, hoat động gây không bào thay đổi rất đáng kể giữa các chủng $\mathrm{H}$. pylori khác nhau, sự thay đổi này chủ yếu do sự khác biệt về cấu trúc gene vacA tại vùng tín hiêu ( $\mathrm{s} 1$ và $\mathrm{s} 2)$ và vùng giữa ( $\mathrm{m} 1$ và $\mathrm{m} 2$ ), do vậy, hậu quả lâm sàng cũng khác nhau với các chủng $\mathrm{H}$. pylori có kiểu gene vacA khác nhau [2]

Trong nghiên cứu của chúng tôi (bảng 5) cho biết: Trong 71 mẫu nghiên cứu, tỷ lệ vacA dương tính: 71/71 (100\%), trong đó vacAs1 $\mathrm{m1}$, vacAs1 $\mathrm{m} 2$ và vacA i 1 chiếm tỷ lệ tương ứng là: $46,5 \%$; $50,7 \%$ và $94,4 \%$.

Hồ Đăng Quý Dũng [6] đã phối hợp với Trường Đại học Oita (Nhật Bản) trên 103 mẫu H. pylori dướng tính ở bệnh nhân VDDM người Kinh (Việt Nam). Kết quả nghiên cứu cho biết: vacA s1 chiếm 103/103 (100\%) và tỷ lệ vacA s1m1, vacAs1m2 chiếm tỷ lệ tương ứng: $44,6 \%$ và $51,5 \%$; có 4 chủng không xác định được kiểu gen chiếm tỷ lệ 3,9\%.
Tại châu Á, tỷ lệ ung thư dạ dày gặp nhiều nhất ở các nước Đông Bắc Á như: Hàn Quốc, Nhật Bản, Mông Cổ và Trung Quốc. Tại các quốc gia gia này tỷ lệ gene cagA Đông Á và gene vacAs1m1 chiếm tỳ lệ cao hơn rất nhiều so với gene cagA phương Tây và gene vacAm1s2 hoặc vacAm2s2 [1],[2] . Do vậy, các gene cagA Đông Á và gene vacAm1s1 đóng vai trò quan trọng có liên quan đến VDDM, loét DDTT và đặc biệt là UTDD.

\section{KẾT LUẬN}

- Tỷ lệ $H$. pylori ở bệnh nhân viêm dạ dày mạn là: 77/121 (63,7\%).

- Tỷ lệ cagA dương tính đạt: 70/71 (98,6\%), trong đó tỷ lệ cagA Đông Á chiếm: $67 / 71(94,4 \%)$.

- Tỷ lệ vacAs1 chiếm: 71/71 (100\%). Phân bố các týp vacA: vacAs1 $m 1$, vacAs $1 \mathrm{~m} 2$ và vacA $i 1$ chiếm tỷ lệ tương ứng là: 46,5\%; 50,7\% và 94,4\%

\section{TÀI LIẸU THAM KHẢO}

1. Yamaoka $Y$. Mechanisms of disease: Helicobacter pylori virulence factors. Nat Rev Gastroenterol Hepatol 2010;7(11): 629-641

2. Uchida $T$, Kanada $R$, Tsukamoto $Y$, et al. Immunohistochemical diagnosis of the cagA-gen genotype of Helicobacter pylori with anti-East Asian CagA-specific antibody. Cancer Sci 2007;98(4): 521-528.

3. Nguyê̂n Quang Chung. (2010). Nghiên cứu lâm sàng, nội soi, mô bệnh học, giai đoan viêm dạ dày và số lượng lymphô bào $T, B$ của viểm da dày man trước và sau diệt Helicobacter pylori. Luận án Tiến sĩ Y hoc (2010)- Viện Nghiên cứu Khoa học Y dược Lâm sà̀ng 108, Hà Nội.

4. Nguyê̂n Văn Thịnh. Nghiên cứu tình trang nhiễm Helicobacter pylori, một số vi khuẩn ky khí khác và những tổn thương niêm mac da dày trong viêm da dày mạn, Luận án Tiến sỹ Y học (2010), Viện nghiên cứu khoa học $Y$ dược lâm sàng 108, Hà Nội.

5. Quách Trong Đức. Mối liên quan giữa teo niêm mạc dạ dày nội soi theo phân loại Kimura Takemoto với các tổn thương tiền ung thư trong bệnh viêm dạ dày mạn. Luận án Tiển sĩ Y học (2011)- Trường Đai học Y dược Thành phố Hồ Chí Minh, thành phố Hồ Chí Minh

6. Hồ Đăng Quý Dũng. Nghiên cứu các týp cag $\mathrm{A}$ vacA của Helicobacter pylori và mối liên quan với nồng độ gastrin, pepsinogen và mô bệnh học của viêm dạ dày mạn. Luận án Tiến sỹ Y học -2011Viện NĆKH Y-Dược Lâm sàng 108

7. Tran Thanh Binh, Vu Van Khien, Yoshio Yamaoka, et al. Molecular epidemiology of Helicobacter pylori infection in a minor Ethnic group of Vietnam: A multiethnic, population based study. International Journal of Molecular Sciences 2018;19(3): 708-715

8. Lê Quang Tâm, Bùi Hữu Hoàng (2012). Viêm loét da dày-tá tràng và nhiễm Helicobacter pylori ở bênh nhân dân tộc Ê Đê tại Bệnh viện tỉnh Đắk Lắk. Tạp chí Y học TP. Hồ Chí Minh, 2012;16(2): 58-67 